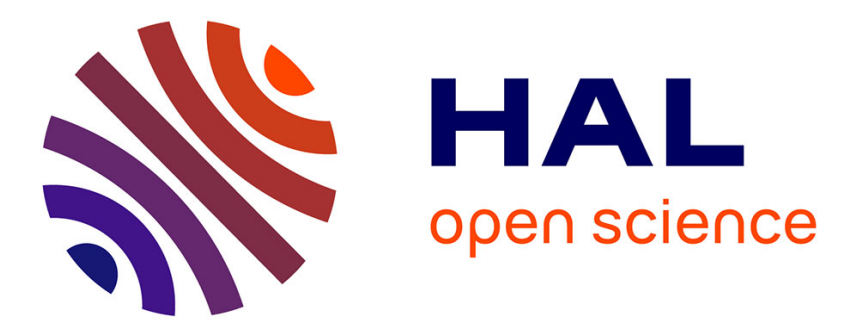

\title{
Selected Knowledge Management Aspects in Modern Education
}

Katarzyna Holowińska

\section{To cite this version:}

Katarzyna Holowińska. Selected Knowledge Management Aspects in Modern Education. 5th IFIP International Workshop on Artificial Intelligence for Knowledge Management (AI4KM), Aug 2017, Melbourne, VIC, Australia. pp.29-39, 10.1007/978-3-030-29904-0_3 . hal-02517702

\section{HAL Id: hal-02517702 \\ https://hal.inria.fr/hal-02517702}

Submitted on 24 Mar 2020

HAL is a multi-disciplinary open access archive for the deposit and dissemination of scientific research documents, whether they are published or not. The documents may come from teaching and research institutions in France or abroad, or from public or private research centers.
L'archive ouverte pluridisciplinaire $\mathbf{H A L}$, est destinée au dépôt et à la diffusion de documents scientifiques de niveau recherche, publiés ou non, émanant des établissements d'enseignement et de recherche français ou étrangers, des laboratoires publics ou privés. 


\title{
Selected Knowledge Management Aspects in Modern Education
}

\author{
Katarzyna Hołowińska \\ Wroclaw University of Economics, Komandorska 118/120 53-345 Wroclaw \\ katarzyna.holowinska@ue.wroc.pl
}

\begin{abstract}
Modern organizations are challenged to permanently be prepared for changes. The competitive advantage can be reached only when organizations are aware what resources are the most essential for the proper functioning. This situation is linked also to the modern education which nowadays have to be more market oriented. Such approach requires greater involvement and allows faster development, thanks to competitiveness which naturally stimulates activity. The main goal of the article is to present new approaches of modern teaching in context of KM. The first part presents roots of KM and it's definition. The second part is connected with challenges of modern education. The last section describes KM tools used as an aspects of present education.
\end{abstract}

Keywords: Knowledge Management, Modern Education, KM tools.

\section{Introduction}

Dynamic continuous development of Knowledge Management (KM) is expanding in new fields like education and caused huge change in this area. Using new technologies, elements of artificial intelligence, complex systems, etc. leads to market oriented organizations including Universities. Efficient KM systems implemented within universities can provide the information about present trends in the jobs market, economy both levels global and local, but also the knowledge accumulated by the university itself and the finest practices of the world best universities. Applying KM on universities can deliver decision support tool which may be connected with broad activities like teaching, research or management [1]. The article presents the description of KM roots and answering the question about what are the tools which can be used in effective KM used in university environment.

Undoubtedly the basic objective of Knowledge Management is extending the innovation capacity of organizations by better use of knowledge, talents or opportunities and technologies. Obviously it is not easy to apply KM mainly because it needs 
certain change of attitude, like listening instead of push, collaborating not competing, gathering, sharing experiences and evaluating the benefits.

\section{Knowledge Management as a Natural Way of PostIndustrial Changes}

The sociological and economical changes which took place recently were connected with transformation from traditional industrial era linked to the traditional values like capital, land and work to new era linked with knowledge where the information is the core resource and determine the competitive advantage on the market. All this changes lead to development of new branch of management the idea of knowledge management. The table below presents the differences between attitudes in industry era and knowledge era. The difference between approaches are diametrically in basic fields in organization.

\begin{tabular}{|c|c|c|}
\hline & Industry era & Knowledge era \\
\hline Basic resource & Capital & Knowledge \\
\hline People (employees) & Cost & Investment \\
\hline Authority & $\begin{array}{c}\text { It depends on position in } \\
\text { structure of the organization }\end{array}$ & $\begin{array}{c}\text { It depends on skills and } \\
\text { knowledge }\end{array}$ \\
\hline Management style & Injunctons and control & Participatory \\
\hline Organizational structure & Hierarchical & Virtual, flat or hypertext \\
\hline Strategy & Focused on competition & Focused on cooperation \\
\hline Organiational culture & Based on obedience & Based on trust \\
\hline Market value & $\begin{array}{c}\text { Depends on financial and } \\
\text { material assets }\end{array}$ & $\begin{array}{c}\text { Depends on intellectual } \\
\text { capitall }\end{array}$ \\
\hline Motivation & Financial incentives & Satisfaction incentives \\
\hline Customer relationship & $\begin{array}{c}\text { Unidirectional through the } \\
\text { market }\end{array}$ & $\begin{array}{c}\text { Interactive through } \\
\text { collaboration }\end{array}$ \\
\hline Continuous change & Threat & Opportunity \\
\hline Development & Linear, predictable & Chaotic, hard to predict \\
\hline Using new technologies & Important & Necessary \\
\hline Dominant sector & Industry & $\begin{array}{c}\text { Service, processing } \\
\text { information }\end{array}$ \\
\hline $\begin{array}{c}\text { The most important } \\
\text { invention }\end{array}$ & Assembly line & Internet \\
\hline Leading companies & Genral Motors, Ford & Microsoft, Amzon \\
\hline
\end{tabular}

Table 1. Comparison of industry era and knowledge era

Source: own elaboration, based on: M. Strojny, Teoria i praktyka zarządzania wiedzą,

„Ekonomika i Organizacja Przedsiębiorstwa”, 2000 
The fundamental element of growth is innovation, but there is no innovation without proper knowledge. With this intensive development of technologies there is a change from traditional approaches to those which use modern solutions to improve efficiency and competitive advantage. This change is also connected with education field which is so crucial for each society. The modern universities competing between each other and this situation shows new perspective. The universities can be perceived as a businesses.

Knowledge management can be considered in variety forms as a process, system, scientific discipline, new philosophy of management. KM can be simply defined as a doing what is needed to get the essence of knowledge resources. The beginnings of $\mathrm{KM}$ was applied to individuals but with the time it is turned out that it also can be used in context of organizations. With this huge amount of information which surrounded us everyday knowledge management is considered as very important discipline. Peter Drucker whom can be consider as a father of KM said, that the knowledge is the key resource and not only in context of economic strength but also as a nation's military strength, he highlighted that there is a need to work on the knowledge in quality and productivity levels. Undoubtedly nowadays the most essential resource of today's organization is the collective knowledge which stays in awareness of whole organizational environment like employees, customers or vendors. Understanding how to organize knowledge in modern enterprises gives many benefits like: developing the most important business competences, increase level of innovation, empowering workers, bringing high quality products to the market, developing time cycles and decision making and finally building strong competitive advantage [1].

The Institute of system production and projecting technologies in Berlin define KM as a set of methods, instruments and tools which have influence on progress of core business processes in context of knowledge which means generating, storage and distribution of knowledge at the same time with using the definition of knowledge aims and identification of the knowledge on all levels and fields of organization [2]. Stewart [2] understand KM as a having a knowledge about the knowledge of particular people, gaining this knowledge and organizing to use it to benefit.

It is possible to find more and more variety definitions of knowledge management but most of them have some common elements. Definitely the idea of knowledge management is based on three main processes: creating, sharing and using the knowledge. With those processes very important in knowledge management systems are: [3]

- technology (Internet, Intranet, Extranet, group work systems), which mean decision support systems or tools which are designed for individual needs

- systems, tools and methods of measuring effectiveness of using the knowledge

- organizational culture which is oriented on people and thanks to this, it is more common to share the knowledge.

Today the most important element of modern management is the knowledge in cooperation with technologies and using it in variety fields. 


\section{Challenges of Modern Education}

Nowadays the access to even latest technology is not a problem caused most of them are intended for mass use, consequently the dynamic of expectations changed. We expect services to be delivered faster, with more modern methods best quality and price. And it is not just about business-related services but also services related to social aspects, progress or education. Especially the last one - education has changed recently. Thanks to the big competition between universities potential students are more like consumers and from this perspective they also making decisions related with education path. Universities rankings are growing in importance and have great influence on perception of universities on the international market. Today students searching services and education with access to new technologies and flexibility in offered options. To be competitive enough and to manage with this precise student expectations universities have to prepare modern facilities and special infrastructure but also new methods of sharing the knowledge. Knowledge Management field has more and more meaning in variety fields. As it turned out not only does it work in corporate business but also in other ground like education field [4].

The main approach in modern education should concentrate on student's individual activity, arrangement of self-learning conditions and useful practical training, but also the whole administration connected with education supposed to be available anytime, easy and reliable. These requirements have been reflected in new teaching methods like e-learning which begin to used not only as a support of classes but more often as a main technique of teaching. Because universities are complex institutions and the flow of knowledge is not only linked to the teaching the students but also with the administration and sharing the knowledge between other organizations that is why the KM tools like Intranets, Document Management, Project Management, Decision Support Systems etc. are so applicable and using them increase the effectiveness of the whole institution. Moreover such methods of teaching like flipping classroom, gamification, using social media or design thinking etc., begin to be more and more popular and seems to be perfect methods which meet requirements of modern education market. Furthermore it is impossible to find one perfect universal teaching method mainly because each student have different perception, and different methods fit to different people. In this case the best solution is the hybridization of few methods is the most effective way which suit especially the biggest groups of students [5]. 


\section{Knowledge Management aspects connected with permanent learn- ing/education}

Unquestionably Knowledge Management contributes to increase competitive advantage as a method of accumulating and proper sharing knowledge between people in whole environment of the organization. To support and control this process organizations may use special tools to organize particular modules of business core which can be used efficiently also in context of Knowledge Management in education[6].

E-learning

The dynamic growth of the Internet definitely have affected the process of learning. Till recently the growth was connected with business to business or business to consumer transactions. Nevertheless the growth of online learning meaning is increasing. According to estimations the learner to education transaction will be third most popular part of the Internet traffic. In addition the World Bank predicted that until 2020 about 90 million students will take part in making degrees or other shorter trainings by distance learning. The estimations of this market shows even more than $\$ 100$ billion value [7].

Rosenberg defines e-learning as a using the Internet for delivering wide selection of solutions which improve knowledge and performance. It is grounded on three basic criteria and characteristic e-learning as a: [8]

- Networked which means that is capable of continuous updating/ storing/ recovering / distributing and sharing information.

- Distributed to the end - user through the computer.

- Focused on the widest view of learning- learning explanations which go beyond the usual models of training.

Training based on the technology has been popular for many years, however the Internet increase the speed, proximity and interaction between learners and teachers. The development of e-learning caused measurable business benefits that can be used on an Intranet and Internet. According to Rosenberg the most important benefits of e-learning are:[8]

- reducing costs;

- improving business responsiveness;

- messages which are reliable and flexible with option to customizing;

- $\quad$ suitable and dependable content;

- unlimited time learning;

- universality;

- can be created by community;

- $\quad$ scaleability.

This change in learning methods will cause risks and opportunities for traditional education and definitely will be a new way for both learners and educators to cope with. Moreover this new paradigm of e-learning requires sometimes different structure and more modern, universal and global attitude. The main element which have influence on this change is technology. Furthermore the technology makes the process of learning more individual and interactive. Tapscott explained the change of interactive learning is a step from traditional one size for all learners to a modern 
attitude of learning which is customized and intended for the individual user. According to Tapscott traditional attitude of learning have been linear opposite to modern attitude which thanks to the Internet is more interactive and non-linear. Such nonlinear learning mean that the user have full control over the learning process [8].

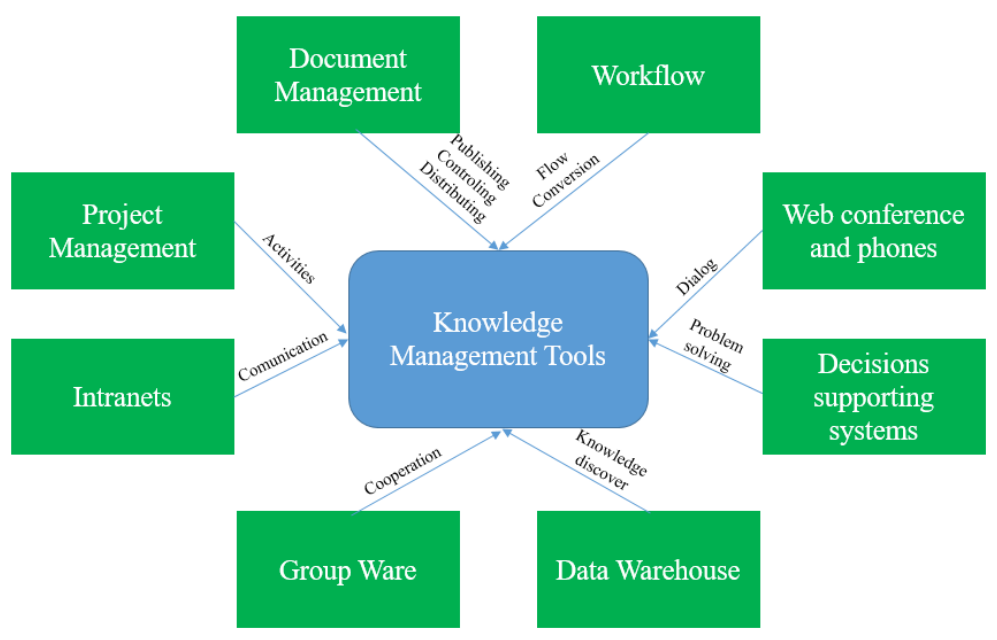

Figure 1. Knowledge Management Tools

Source: own elaboration, based on: A Tiwana Knowledge Management Toolkit,

- Document management

Naturally universities have a lot of important information exist in paper form. That is why there is a need to change it into a more transferable and searchable electronic form by scanning. It is important to noticed that this action should not be considered as a Knowledge Management initiative. Sometimes converting and cataloging the most important information for the organization is simply sufficient. However using the tools which supporting versioning of the document during the teams working on documentation or creating new documents can be very helpful. This guarantee that all team members have access to the most updated version of particular document and it is helping to avoid working on inconsistent versions. Document management includes also capacity of developing the documents database and categorize them automatically. In such institution like university this kind of solution provide consistent and well maintained the policy of managing with documents in whole organization.

- Workflow

The tools which support workflow in the organization allows users to easily make visualization and automatization of the current processes, but also gives possibility to monitor progress or even modify those processes in real time. This kind of tool is especially useful in environment like universities where appear many processes and projects which require some control to avoid chaos.

- Web conference and phones 
The phones and web conferences seems to fit perfect for the characteristic of effective knowledge management tool as an instrument which let to develop informal cooperation, discussion and chats. This tool appeared in following forms:

- Virtual meetings, give possibility for users in different localizations to connect, manage the meeting and share the information. In addition users have options to share applications in form of the screens, graphics, word processing or spreadsheets in real time.

- Document collaboration, let users to cooperate with all team members or other participants on variety forms of documents or programs in real time. The users not only can view shared information but can also take control of the shared programs and fill or edit some data there.

- Informal communication, it is also important to highlight that the chats may take place with natural voice and with the virtual presence. The academic research has shown that people who have possibility to see each other face to face create trust more easily.

All those proposals give chance to shorten the geographic distance as if it were not exist at all, and obviously it give great work effectiveness especially in such environment like educational institution.

- Decisions Supporting Systems

Those systems help to make minor and major decisions quick and correctly thanks to analysis of historical data and past experiences. Data mining instruments support in finding precise trends and patterns from data warehouses.

- Data Warehouse

A tool used in case when university is using multiplication of the databases which are existing in hierarchy and data warehouse uniform all of this databases. This tool provide possibility to use several different databases at the same time, merge their content, run queries at once or reduce data chaos. Because data warehouses collective and combine data from various sources and collect data in process this solution increase the quality of data.

- Group Ware

Obviously the process of making, distributing and using knowledge involves cooperation. Innovative activities based on knowledge are intensively cooperative. GroupWare instruments deliver document repository, remote integration and ground for cooperative work.

- Intranets

Availability of the information capital inside and outside a university gives possibility that the information which are needed have already exist. In this case the most important aspect is to find efficient solution to access to this data and easy distribute it where it was requested. The Intranet is used similar to the Internet but it is private and secure which is very important for fragile data which organizations are using. Moreover Intranet is cost effective and allows limitless communication across geographical boundaries. In case of university the idea of Intranet can be used not only for the stu- 
dents but also for the teachers and administration employees which gives possibility to share the knowledge in very quick way but also additional information like grades, schedules or administrative changes.

- Project Management

Project management tools afford for high level of university to actions which are connected with creation of knowledge. This tools provide users to trace back artifacts and documents which might have caused from previous project. Despite of the project management tools meaning in creation of knowledge in organization is partial, this instruments can offer good foundation for storing and organizing all documents used in organization. In addition project management tools give possibility to connect used resources to the project management document, create reports or trace referenced hyperlinks. Thanks to this solution universities can exchange the best practice also between each other[9].

\section{$4 \quad$ Knowledge Management benefits}

The benefits of knowledge management relate to three levels: organizations, employees and to the market.

1. Organizations level. For the organization, the benefits of knowledge management are established on two levels: inside of the organization and the outside of the organization (environment).

The benefits of knowledge management inside of the organization include[10]:

a) increase of management efficiency: organizational culture allowing easy access to knowledge assets, building a new strategy, free flow of knowledge, increased importance of research, exchange of the best experiences, change in relations with clients and market partners, easy access to experts, dynamic development of information technology in the organization;

b) employee development: knowledge sharing among employees, employee systems motivation, systems staff development (increase in key competences), coaching, mentoring, team working (higher work efficiency);

c) improvements in communication inside of the organization: internal procedures establishing the principles of acquiring, processing and implementing knowledge (information), implementation of information technology.

d) reduction of management costs: by saving time, codification of knowledge, quick access to knowledge assets;

e) improve of creativity and innovation: exchange of knowledge and experience, focusing in employee development, building communities of practitioners and task teams;

f) increase in the flexibility of organization management: quick response on the environment information, constant monitoring of the market situation.

The flow benefits of the external organizational level is about defense and development of the market position and increase in competitiveness through: 
a) enterprise development: creating new values, continuous improving all aspects and at all levels of the organization;

b) increase in the competitiveness of employees and enterprises: continuous employee education and qualifications, effective use of the employees potential;

c) increase in the efficiency of action: limiting management costs, improvements in human resource management

d) flexibility in adapting to the market needs: predicting client's and market partner's needs, as well as competition moves;

e) innovation: creating new products and improving quality of products and services

f) changes in customer relations: shaping a positive image of the company.

2. Employee level. The benefits of knowledge management apply not only to the organization but also to the employees. Creating an organizational culture cause free flow of the knowledge and leads employees development.

The benefits of knowledge management at the employee level are[11]:

a) continuous development,

b) improving competences,

c) easy access to knowledge resources: better work performance and higher effecitvness,

d) saving time: necessary to gain proper data,

e) creativity: generating new values for the organization,

f) self-realization,

g) positive attitude to the work.

3. Market level. The benefits of knowledge management in context of market include both market partners - suppliers and customers as well as competitors. Such cooperation brings following benefits:

a) fluent exchange of information, knowledge and experiences: in context of different organizations and cultures,

b) understanding customer needs: new ideas for products and services,

c) media effect: the company prestige increases and causes valuable business contacts,

d) constant control of market changes: useful in preparing organization strategy.

The main result of all benefits is to shape efficient management system which consist new organizational strategy and organizational culture based on knowledge management and support by the information technologies. 


\section{Conclusions}

Certainly new technologies will motivate institution connected with education to analysis and consideration about the entire process of learning and teaching. It gives possibility to simplify learning chances for individuals. Definitely it is still much work to do in field of modern education and the possibilities of development are very broad.

The main findings of the papers can be formulated as follows:

1) Modern education needs to be systematically changed in order to react on actual challenges like modifying universities in the institution which are oriented more on the market by implementing new technologies, deploy new trends, follow and react on student expectations.

2) There is a bigger and bigger importance of information technology in modern education. One of the most popular method which universities are using on their portals is e-learning which gives completely new possibilities of learning more focused on individual needs and skills of the users. Moreover this method can quickly measure the progress and possibility to establish proper program of learning.

3) Universities and other educational institutions are obliged to apply knowledge management tools in didactics as well in other areas of their activities. In addition universities are using also tools which are useful in the administration like document management, project management or intranet. It improves the work of employees and provides continuous access to current information for the students Certainly this is the added value that enhances the competitive advantage.

The future research about developing and using new methods, tools and approaches in field of education will definitely focus more on effectiveness especially in context of individual needs of students but also in hybridization of the most efficient methods. Universities noticed that Knowledge Management is the key element which may generate measurable results in quality of teaching and organizing work. Such conditions favor the perception of the institution as an attractive place to develop its skills and knowledge which is so important in context of institution like university.

Undoubtedly the basic objective of Knowledge Management is extending the innovation capacity of organizations by better use of knowledge, talents or opportunities and technologies. Obviously it is not easy to apply KM mainly because it needs certain change of attitude, like listening instead of push, collaborating not competing, gathering, sharing experiences and evaluating the benefits. [10] 


\section{References}

[1] Mihaela Oprea, A University Knowledge Management Tool for Academic Research Activity Evaluation, Informatica Economică vol. 15, no. 3/2011,

[2] I Becerra-Fernandez, Rajiv Sabherwal, Knowledge management: Systems and Processes, Routledge, New York, 2015,

[3] B. Mikuła, A. Pietruszka-Ortyl, A. Potocki, Zarządzanie przedsiębiorstwem XXI wieku. Wybrane koncepcje i metody, Difin, Warszawa 2002,

[4] M. Strojny, Teoria i praktyka zarządzania wiedzą, Ekonomika i Organizacja Przedsiębiorstwa, 2000,

[5] https://beyond2015.acu.ac.uk/submissions/view?id=106

[6] Marciniak K., Owoc M.L.: Knowledge Management as Foundation of Smart University. Maria Ganzha, Leszek A. Maciaszek, Marcin Paprzycki (eds.): Federated Conference on Computer Science and Information Systems - FedCSIS 2013, Kraków, Poland, 8-11 September 2013, Proceedings, 2013

[7] G. Jones, E. Sallis, Knowledge Management in Education: Enhancing Learning \& Education, Routledge, 2002

[8] J. Liebowitz, M. Frank, Knowledge Management and E-Learning,CRC Press, 2010

[9] V. Arkorful, N Abaidoo, The role of e-learning, advantages and disadvantages of its adoption in higher education. International Journal of Instructional Technology and Distance Learning, 2015

[10] Błaszczuk A., Brdulak J.J., Guzik M., Pawluczuk A., Zarządzanie wiedzą w polskich przedsiębiorstwach, Szkoła Główna Handlowa, Warszawa 2004.

[11] Kwiecień K., Majewski M., Tajniki wykorzystania wiedzy, w: Zarządzanie wiedzą w przedsiębiorstwie, Materiały konferencyjne, Polska Fundacja Promocji Kadr, Warszawa 2001.

[12] E. Mercier-Laurent, Knowledge Management \&Risk Management, Federal Conference on Computer Science and Information Systems, 2016

[13] A Tiwana Knowledge Management Toolkit, Prentice Hall PTR, 2002 